\title{
PELATIHAN WIRAUSAHA DIGITAL DENGAN SISTEM BLENDED LEARNING PADA KOMUNITAS BELAJAR DARON LABS DI KOTA PADANG
}

\author{
Ulfia Rahmi ${ }^{1}$, Alwen Bentri ${ }^{2}$, Azrul ${ }^{3}$ \\ ${ }^{1,2}$, Teknologi Pendidikan, Fakultas Ilmu Pendidikan \\ ${ }^{3,}$ Ilmu Pendidikan, Pascasarjana, Universitas Negeri Padang \\ Email: ulfia@fip.unp.ac.id
}

\begin{abstract}
Nowadays, Indonesia is preparing for a crucial and profitable period, namely the demographic bonus which is expected to reach the point in the years of 2025-2030, but the number of unemployed are increase every year. Regarding the problem, the government has also encouraged the public to open employment opportunities with entrepreneurship. Daron Labs is a group of people who form a learning community to develop beginner entrepreneurial skills. Entrepreneurial skills transmitted by Daron Labs to prepare the community to become digital entrepreneurs, including: video makers, web designers, graphic design, and programmers. Members of this learning community are free to choose the material of interest according to the needs of each member. In this Community Service, the learning community of Daron Labs chose the location of Padang City with the consideration that the city of Padang represented the people of West Sumatra. The Daron Labs Padang community accepts members of the learning community from all community groups to develop their entrepreneurial skills. The methods offered for organizing the Daron Labs learning community through a blended learning for three months. Face-toface meetings are twice a month and material is sent every week. Participants' responses indicate that this program is expected to continue and provide debriefing in other fields of digital entrepreneurship.

Keywords: Blended Learning, Digital Entrepreneurship, Learning Community
\end{abstract}

\begin{abstract}
Abstrak. Indonesia pada saat ini mempersiapkan diri untuk masa yang krusial sekaligus menguntungkan yaitu bonus demografi yang diperkirakan akan terjadi puncaknya pada tahun 2025-2030, namun jumlah pengangguran terus meningkat. Terkait masalah tersebut, pemerintah mendorong masyarakat membuka lapangan pekerjaan dengan berwirausaha. Daron Labs merupakan sekelompok masyarakat yang membentuk komunitas belajar untuk mengembangkan keterampilan wirausaha. Keterampilan berwirausaha yang dilakukan oleh Daron Labs untuk mempersiapkan wirausahawan digital meliputi videomaker, webdesigner, desain grafis, dan programer. Anggota komunitas belajar ini bebas memilih materi yang diminati sesuai dengan kebutuhan anggota. Pada Pengabdian kepada Masyarakat ini komunitas belajar Daron Labs memilih lokasi Kota Padang dengan pertimbangan bahwa kota Padang merepresentasikan masyarakat Sumatera Barat. Komunitas Daron Labs Padang menerima anggota komunitas belajar dari seluruh kalangan masyarakat. Metode yang ditawarkan untuk penyelenggaraan komunitas belajar Daron Labs melalui sistem blended learning yang diselenggarakan selama tiga bulan. Pertemuan tatap muka diselenggarakan dua kali dalam satu bulan dan setiap minggunya dikirimkan materi kepada peserta belajar. Respon peserta menunjukkan bahwa program ini diharapkan terus berlanjut dan memberikan pembekalan pada bidang wirausaha digital lainnya.
\end{abstract}

Kata kunci : Blended Learning, Kewirausahaan Digital, Komunitas Belajar

\section{PENDAHULUAN}

Indonesia sekarang sedang berada pada suatu tahapan yang saat krusial dan menentukan. Terutamanya sebagai sebuah bangsa yang masih dalam masa pembangunan. Oleh sebagian besar ahli ilmu sosial, tahapan krusial ini disebut sebagai era bonus demografi. Dimana era tersebut sebenarnya sudah dimulai dan diperkirakan akan mencapai puncaknya pada rentang waktu tahun 2025-2030. Bonus demografi adalah suatu keadaan dimana jumlah penduduk usia produktif lebih besar dibandingkan dengan jumlah penduduk usia non produktif. Kondisi demikian, memiliki nilai 
positif dan keuntungan besar bila dikelola secara profesional.

Permasalahan terkini di Indonesia adalah meningkatnya jumlah pengangguran setiap tahun. Pengangguran tersebut berasal dari kalangan berpendidikan dan tidak berpendidikan dengan jumlah penduduk Indonesia sekitar 260 juta orang. Indonesia adalah negara berpenduduk terpadat keempat di dunia (setelah Cina, India dan Amerika Serikat). Indonesia juga memiliki populasi penduduk yang muda karena sekitar setengah dari total penduduk Indonesia berumur di bawah 30 tahun. Jika kedua faktor tersebut digabungkan, indikasinya Indonesia adalah negara yang memiliki kekuatan tenaga kerja yang besar, yang akan berkembang menjadi lebih besar lagi ke depan, maka menekankan pentingnya penciptaan lapangan kerja dalam perekonomian terbesar di Asia Tenggara. Indonesia di tingkat Asia Tenggara juga memiliki tingkat pengangguran yang relatif besar. Indonesia berada pada urutan ketiga dari sepuluh negara (Grafik 1).

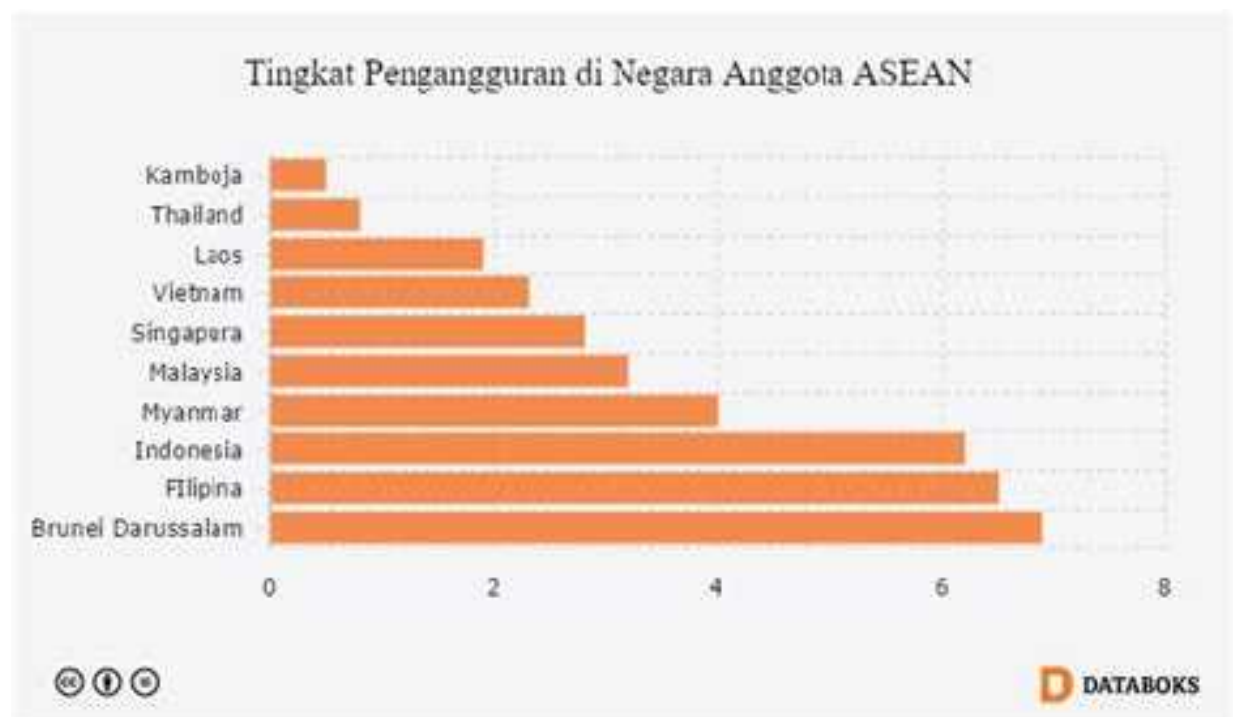

Grafik 1. Tingkat Pengangguran di Negara ASEAN

Jumlah pengangguran di perkotaan dan pedesaan di Indonesia, jumlah pengangguran secara signifikan lebih tinggi di daerah perkotaan dibandingkan dengan daerah pedesaan. Yang tidak kalah menariknya yaitu kesenjangan antara pengangguran perkotaan dan pedesaan melebar selama empat tahun terakhir karena pengangguran pedesaan telah menurun lebih cepat daripada pengangguran di perkotaan. Penjelasan untuk tren ini adalah bahwa banyak orang pedesaan pindah ke daerah perkotaan dalam rangka mencari peluang kerja.

Terkait masalah tersebut, pemerintah juga telah mendorong masyarakat untuk membuka lapangan pekerjaan dengan berwirausaha. Masalah yang ditemukan adalah sulitnya wirausahawan tersebut memulai kegiatan usaha disebabkan oleh faktor ide wirausaha, modal, masyarakat, peluang, dan minimnya keterampilan yang dibutuhkan dalam berwirausaha.
Kompleksitas dari permasalahan tersebut bermuara pada tidak melakukan tindakan apa-apa dan hanya menunggu panggilan kerja atau penerimaan pegawai negeri sipil. Jikapun ada masyarakat yang ingin berwirausaha, mereka terkendala dengan sistem permbelajarannya. Data menunjukkan bahwa yang berminat berwirausaha tidak hanya yang belum bekerja, tetapi pekerja dan para profesional juga tertarik untuk berwirausaha. Dengan aktivitas dan rutinis yang mengikat, mereka kesulitan untuk mengembangkan keterampilan berwirausahanya.

Pengabdian kepada masyarakat ini ingin menawarkan solusi kepada masyarakat untuk mengikuti pengembangan keterampilan wirausaha dengan sistem blended learning. Sistem ini menawarkan fleksibelitas waktu dan tempat untuk belajar karena tidak harus datang ke kelas untuk mempelajari keterampilan yang mereka minati. Pertemuan tatap muka akan 
diselenggarakan dua kali dalam satu bulan dan setiap minggunya akan dikirimkan materi kepada peserta belajar selama tiga bulan. Penerapan blended learning ini melalui mitra pengabdian kepada masyarakat.

Mitra pengabdian kepada masyarakat ini adalah Daron Labs. Daron Labs merupakan komunitas belajar yang berfokus pada pengembangan keterampilan wirausaha yang tidak produktif secara ekonomi dan sosial. Daron Labs merupakan sekelompok masyarakat yang membentuk komunitas belajar untuk mengembangkan keterampilan wirausaha pemula. Keterampilan berwirausaha yang ditularkan oleh Daron Labs untuk mempersiapkan masyarakat agar menjadi wirausahawan, videomaker, webdesigner, desain grafis, dan programer. Mitra adalah kelompok masyarakat yang tidak produktif secara ekonomi. Mitra berlokasi di Sumatera Barat, khusus untuk pengabdian kepada masyarakat ini berfokus di Kota Padang. Berdasarkan kesepakatan tim Pengabdian kepada masyarakat dengan mitra,
DILO dipilih sebagai tempat untuk melanjutkan kegiatan pembekalan kewirausahaan ini. DILO adalah fasilitas berupa meeting room yang disediakan oleh PT Telkom untuk melakukan berbagai kegiatan oleh beragam komunitas yang membutuhkan. Terumata untuk pengembangan diri.

\section{METODE PELAKSANAAN}

Pengabdian kepada masyarakat ini diselenggaran di Digital Innovation Lounge (DILO) Kota Padang. Dilo beralamat di Jl. Batang Tarusan No.3, Alai Parak Kopi, Kec. Padang Utara, Kota Padang, Sumatera Barat 25139. DILO dipilih sebagai tempat untuk melanjutkan kegiatan pembekalan kewirausahaan ini. DILO adalah fasilitas berupa meeting room yang disediakan oleh Telkom untuk melakukan berbagai kegiatan oleh beragam komunitas yang membutuhkan. Terutama untuk pengembangan diri. Gambar 2 berikut adalah jarak kampus pusat UNP dengan lokasi pengabdian kepada masyarakat.

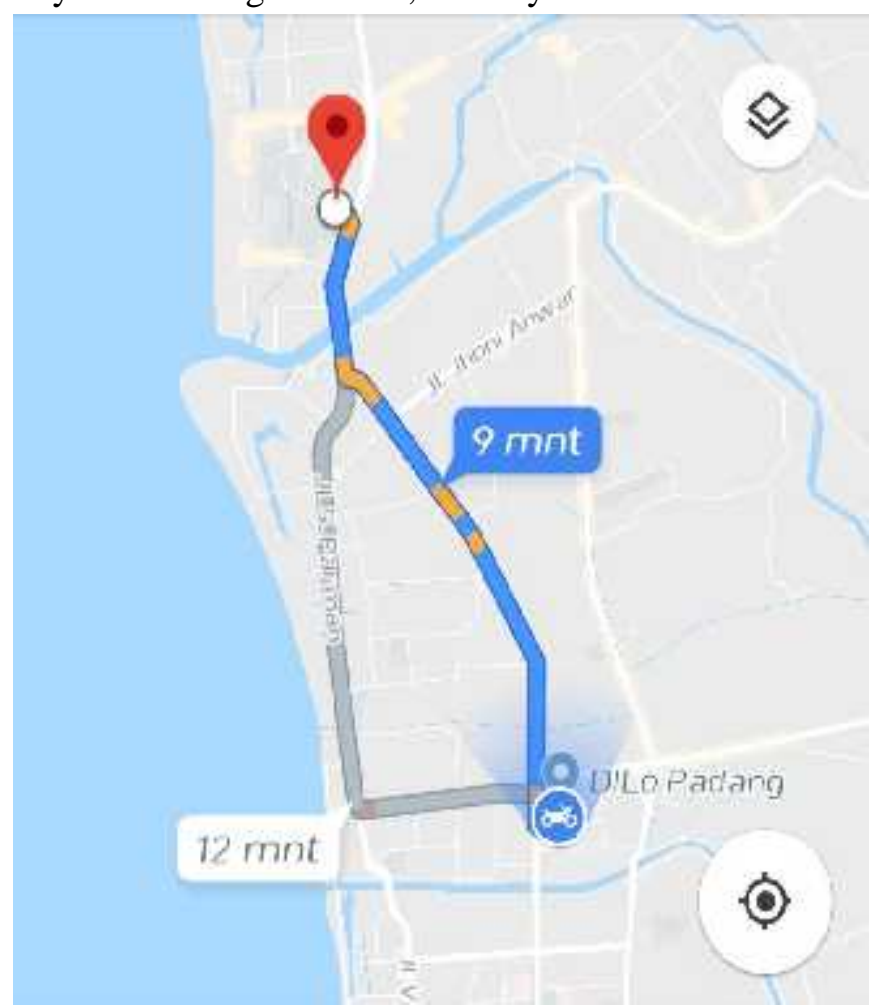

Gambar 2. Lokasi Pengabdian kepada Masyarakat

Metode penyelenggaraan komunitas belajar Daron Labs melalui sistem blended learning yang diselenggarakan selama tiga bulan. Pertemuan tatap muka akan diselenggarakan dua kali dalam satu bulan dan setiap minggunya akan dikirimkan materi kepada peserta belajar. Pendidikan, pelatihan dan workshop dilakukan setiap hari kamis selama tiga bulan. Materi pada 
jadwal tersebut diselang-selingi dengan film maker 6 kali pertemuan pada minggu kedua kebutuhan peserta. Misalnya webprogramer 6 dan keempat.

kali pertemuan minggu pertama dan ketiga, dan

Tabel 1.1 Jadwal Kegiatan

\begin{tabular}{|l|l|l|l|}
\hline Bulan I & Bulan II & Bulan III \\
\hline & & & \\
\hline & & & \\
\hline & & & \\
\hline & & & \\
\hline
\end{tabular}

: materi webprogramer
: materi filmmaker

\section{HASIL DAN PEMBAHASAN}

Respon peserta menunjukkan bahwa program ini diharapkan terus berlanjut dan memberikan pembekalan pada bidang wirausaha digital lainnya. Daron Labs telah melakukan berbagai bentuk kegiatan pembekalan di bidang multimedia dengan melibatkan siswa, mahasiswa, guru, dosen, pekerja, dan masyarakat umum. Namun dalam pelaksanaan programnya Daron Labs terkendala dalam rancangan kegiatan pendidikan, pelatihan dan workshop disebabkan beragamnya latar belakang peserta belajar. Daron Labs membutuhkan pembelajaran yang lebih menarik dan tidak monoton dalam kegiatan pendidikan, pelatihan dan workshop. Dengan beragam latar belakang peserta, Daron Labs juga membutuhkan model pendidikan non formal yang mengakomodasi banyak peserta. Untuk menyelenggarakan kegiatan pendidikan, pelatihan dan workshop yang menarik tersebut dibutuhkan model blended learning yang didukung oleh multimedia pembelajaran. Dan kendala terbesar komunitas ini karena berupa mitra yang tidak produktif secara ekonomi sangat minim dana untuk mensukseskan program yang Daron Labs garap.

Berikut beberapa foto kegiatan yang sudah dilakukan oleh Daron Labs.

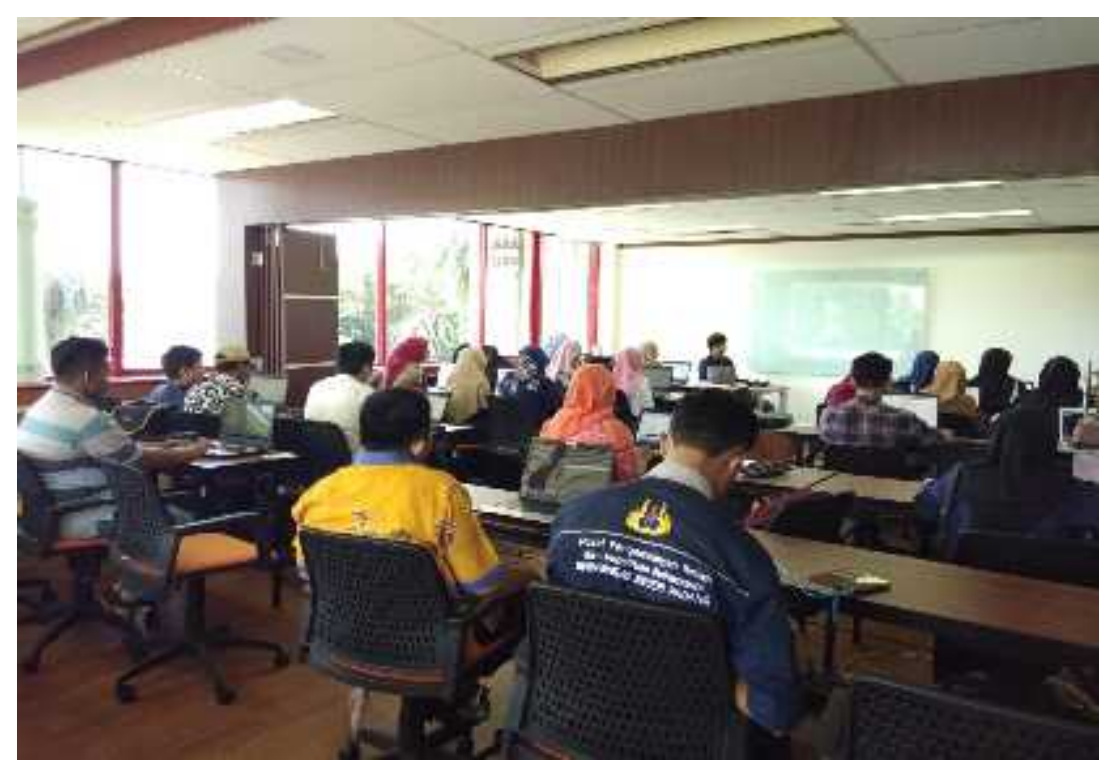

Gambar 3. Peserta Komunitas Belajar Daron Labs Sedang Antusias Memperhatikan Penjelasan Pemateri 


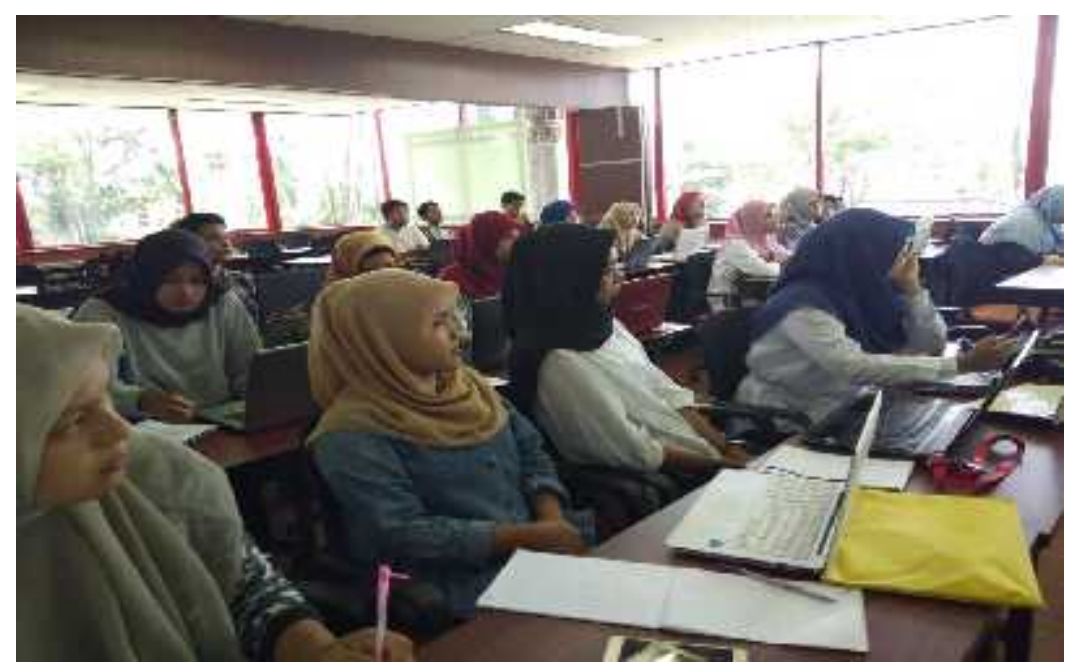

Gambar 4. Peserta Komunitas Belajar Daron Labs Sedang Antusias Memperhatikan Penjelasan Pemateri Tampak Depan

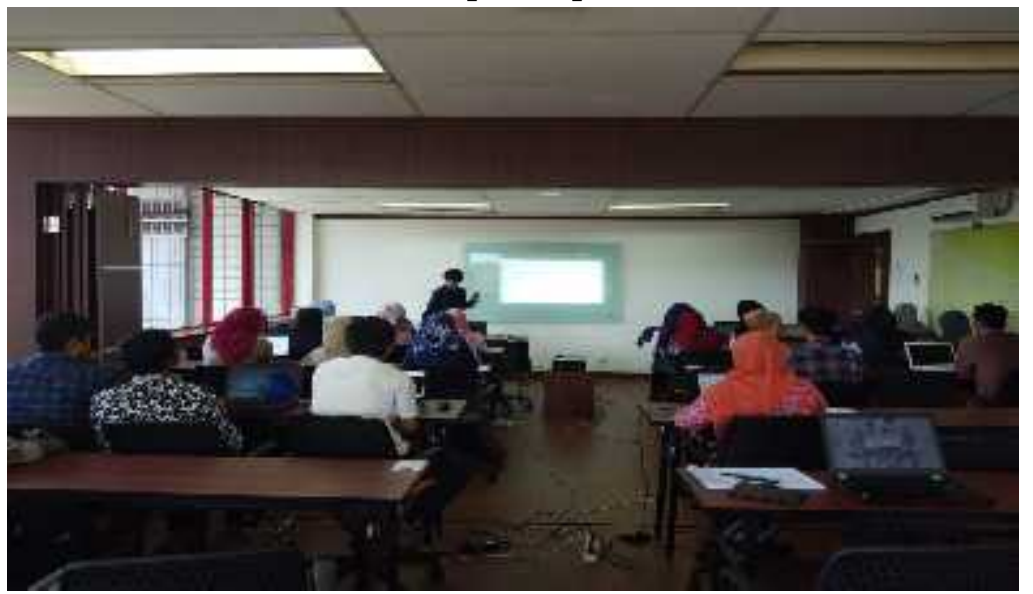

Gambar 5. Instruktur Menyajikan Materi Webprogramer kepada Peserta Komunitas Belajar Daron Labs

Anggota komunitas belajar ini bebas menekan angka pengeluaran dalam pelaksanaan memilih materi yang diminati sesuai dengan kebutuhan masing-masing anggota. Pada Pengabdian kepada Masyarakat ini komunitas belajar Daron Labs memilih lokasi Kota Padang dengan pertimbangan bahwa kota Padang merepresentasikan masyarakat Sumatera Barat. Komunitas Daron Labs Padang menerima anggota komunitas belajar dari seluruh kalangan masyarakat untuk dikembangkan keterampilan berwirausahanya.

Permasalahan yang dihadapi mitra diatasi dengan menerapkan sistem pembelajaran blended learning. Sistem ini menawarkan fleksibelitas waktu dan tempat untuk belajar pada komunitas Daron Labs, sistem blended learning akan mengkombinasikan pembelajaran workshop tatap muka dengan pembelajaran daring melalui pengoptimalan teknologi informasi dan komunikasi dengan sistem blended learning akan pembelajaran tanpa mengabaikan kualitas yang diharapkan karena tidak harus datang ke kelas untuk mempelajari keterampilan yang mereka minati (Bersin, 2004; Kaur, 2013; Rahmi, 2016).

Pertemuan tatap muka diselenggarakan dua kali dalam satu bulan dan setiap minggunya akan dikirimkan materi kepada peserta belajar selama tiga bulan. Penerapan blended learning ini melalui mitra pengabdian kepada masyarakat. Dengan sistem blended learning akan melahirkan masyarakat wirausahawan, videomaker, webdesigner, desain grafis, dan programer yang siap berwirausaha. Sistem tatap muka dan daring juga akan menghadirkan narasumber yang kompeten dan terkait langsung dengan bidang yang dipelajari seperti ahli web programer, narsumber videographer dan lainnya.

Solusi yang tim PKM berikan adalah penyelenggaraan komunitas belajar Daron Labs 
dengan sistem blended learning. Solusi ini dilandasi oleh penelitian-penelitian sebelumnya, yaitu a) model blended learning sesuai karakteristik mata kuliah di program studi Teknologi Pendidikan (Rahmi, 2013), b) formulasi strategi penerapan blended learning (Bentri et al., 2014), c) daya serap mahasiswa dengan penerapan blended learning(Hidayati, Bentri, \& Rahmi, 2015), d) model desain pesan blended learning (Rahmi, Mawardi Effendi, \& Ansyar, 2017), e) perangkat pembelajaran sesuai dengan desain pesan (2016) (Rahmi, Effendi, Ansyar, \& Jasrial, 2016), f) media blogfolio dalam blended learning (Rahmi, Syafril, \& Azman, 2017), dan g) instrumen penilaian dalam sistem blended learning yang sedang dikaji tahun ini (Bentri, Rahmi, \& Hidayati, 2018). Dari riset tersebut, tim memiliki kompetensi untuk menyelenggarakan blended learning di pendidikan non formal, salah satunya Daron Labs. Dan hasil pengabdian kepada masyarakat yang dilakukan bersama mitra Daron Labs ini bahwa kegiatan-kegiatan pelatihan penigkatan keterampilan digital pendukung untuk berwirausaha digital dibutuhkan masyakakat, terutama Kota Padang.

\section{SIMPULAN DAN SARAN}

Simpulan penerapan sistem blended learning untuk meningkatkan kemampuan wirausaha digital pada daron labs kota padang efektif untuk meningkatkan keterampilan digital peserta khusus keterampilan pembuatan video dan pengembangan website. Respon peserta menunjukkan bahwa program ini diharapkan terus berlanjut dan memberikan pembekalan pada bidang wirausaha digital lainnya.

\section{UCAPAN TERIMAKASIH}

Ucapan terimakasih disampaikan kepada 1) kegiatan ini dibiayai oleh Hibah Pengabdian kepada Masyarakat oleh KEMRISTEKDIKTI, dan 2) Kepada Daron Labs sebagai Mitra.

\section{DAFTAR PUSTAKA}

Bentri, A., Rahmi, U., \& Hidayati, A. (2018). MODEL INSTRUMEN PENILAIAN BLENDED LEARNING DI PERGURUAN
TINGGI. Padang.

Bentri, A., Zen, Z., Rahmi, U., Kurikulum, J., Teknologi, D., Fakultas, P., ... Padang, U. N. (2014). FORMULASI STRATEGI PENERAPAN BLENDED LEARNING DALAM IMPLEMENTASI KURIKULUM DI JURUSAN KTP FIP UNIVERSITAS NEGERI PADANG. Jurnal Penelitian Pendidikan, 5(1).

Bersin, J. (2004). The Blended Learning Book. San Francisco: John Wiley \& Sons, Inc.

Hidayati, A., Bentri, A., \& Rahmi, U. (2015). Daya Serap Mahasiswa terhadap Materi dengan Penerapan Blended Learning di Fakultas Ilmu Pendidikan Universitas Negeri Padang. Padang.

Kaur, M. (2013). Blended learning-its challenges and future. Procedia-Social and Behavioral Sciences, 93, 612-617.

Rahmi, U. (2013). Pengembangan Model Pembelajaran Blended Learning pada Mata Kuliah Desain Pembelajaran Berbasis Komputer di Fakultas Ilmu Pendidikan Universitas Negeri Padang. Universitas Negeri Padang.

Rahmi, U. (2016). Desain Sistem Pembelajaran Blended Learning: Upaya Peningkatan Kualitas Pendidikan di Indonesia. INSIGHT Vol 1, 122-137.

Rahmi, U., Effendi, Z. M., Ansyar, M., \& Jasrial. (2016). The Model of Instructional Message Design in Blended Learning. Proceeding International Seminar on Education The2nd, 1, 260-270. Fakultas Ilmu Pendidikan UNP.

Rahmi, U., Mawardi Effendi, Z., \& Ansyar, M. (2017). The Development of MessageDesign Model in Blended Learning. The Asian Journal of Technology Management, 10(1), $1-9$. https://doi.org/10.12695/ajtm.2017.10.1.1

Rahmi, U., Syafril, \& Azman. (2017). Blogfolios dalam Blended Learning sebagai Sarana dalam Pengembangan Kemampuan Pemrosesan Informasi Mahasiswa di Era Digital pada Program Studi Teknologi Pendidikan FIP UNP. Padang. 